\title{
皮下腫瘤の臨床診断における超音波の有用性
}

\author{
東 直行 ${ }^{1}$ 林 綾子 ${ }^{2}$ 佐藤 寛之 ${ }^{2}$ \\ ${ }^{1}$ 日本医科大学多摩永山病院皮虐科 \\ ${ }^{2}$ 日本医科大学多摩永山病院中央検査室
}

\section{Efficiency of Ultrasound for the Clinical Diagnosis of the Subcutaneous Tumor}

\author{
Naoyuki Higashi ${ }^{1}$, Ayako Hayashi ${ }^{2}$ and Hiroyuki Sato ${ }^{2}$ \\ ${ }^{1}$ Department of Dermatology, Nippon Medical School Tama Nagayama Hospital \\ ${ }^{2}$ Division of Laboratory Medicine, Nippon Medical School Tama Nagayama Hospital
}

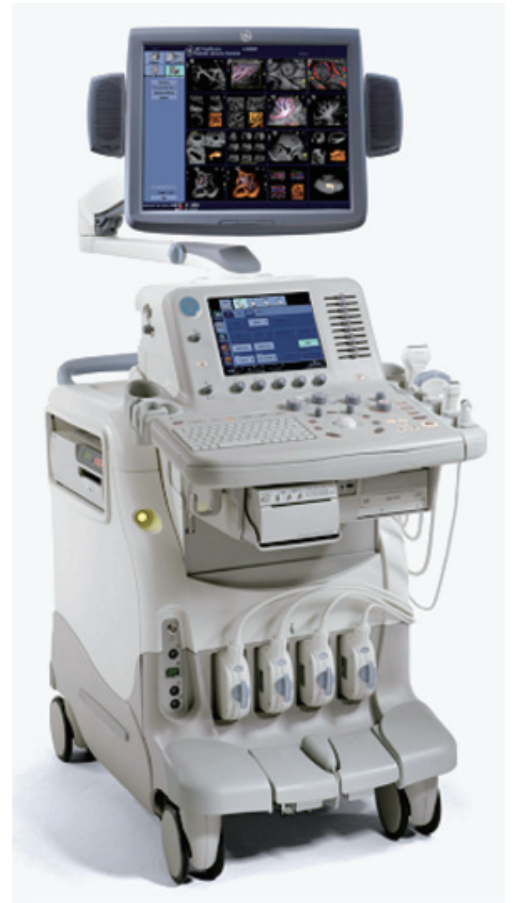

図 1

超音波（エコー）検査は，近年皮膚科領域でも皮下腫瘤 の診断で使用されている．当科では，中央検査室の協力を 得て, 1,282 例（2006 年 1 月〜2010 年 12 月）に実施し, 手術症例 $(499$ 例 $(39 \%))$ では病理組織検査と皮膚エコー の結果を照合し，その診断精度を上げる取り組みを行って いる．皮膚エコーの利点は， 1 , 非侵襲的で, 簡便, ほか の画像診断に比べ安価. 2, 典型例では診断が容易. 欠点 は，1，被髪頭部は実施しにくい．2，特徵的所見にそしい

図 $1 \mathrm{GE}$ ヘルスケア・ジャパン社の超音波診断機 LOGIQ 7 を使用し, $14 \mathrm{MHz}$ のプローブを用いている.

図 $2 \mathrm{a}$ : 粉瘤: 炎症のない典型例では囊腫構造と側方の 著明な低エコー, 底部後方の高エコー. $\mathbf{b}$ : 石灰化上皮腫 : 石灰成分の沈着程度で変わるが, 薄い高エコーより後方で
場合は除外診断的になることがある. と考える. 皮膚エコー は， 欠点に記載した症例や腫瘍サイズが大きい症例では, MRI，CT といったほかの画像診断と組み合わせること で, 術前に, より臨床診断を絞り込み, 有用な情報を提供 してくれる診断機器であるといえる. 図 2 に典型的な皮下 腫瘍の皮膚エコー所見を供覧した。これら以外に, 異物, 脂肪腫, 血管平滑筋腫, 皮膚線維腫, 血管腫, 血栓, 皮膚 幼虫移行症の虫体などにも皮膚エコーが有用である。

は著明な低エコーを示す. $\mathrm{c}$ : 反応性リンパ節腫脹 : 周囲 より低エコーの楕円領域, 内部の中央に線状のやや高エ コー（リンパ節門）が見られる. d：ガングリオン：囊腫 構造があり著明な低エコーで, 場合によっては関節との連 続性も確認できることがある. e, f : 悪性腫痬（類上皮肉

連絡先：東 直行 $\overline{\mathbf{T}} 206-8512$ 東京都多摩市永山 1-7-1 日本医科大学多摩永山病院皮膚科

E-mail: ton@nms.ac.jp

Journal Website (http://www.nms.ac.jp/jmanms/) 

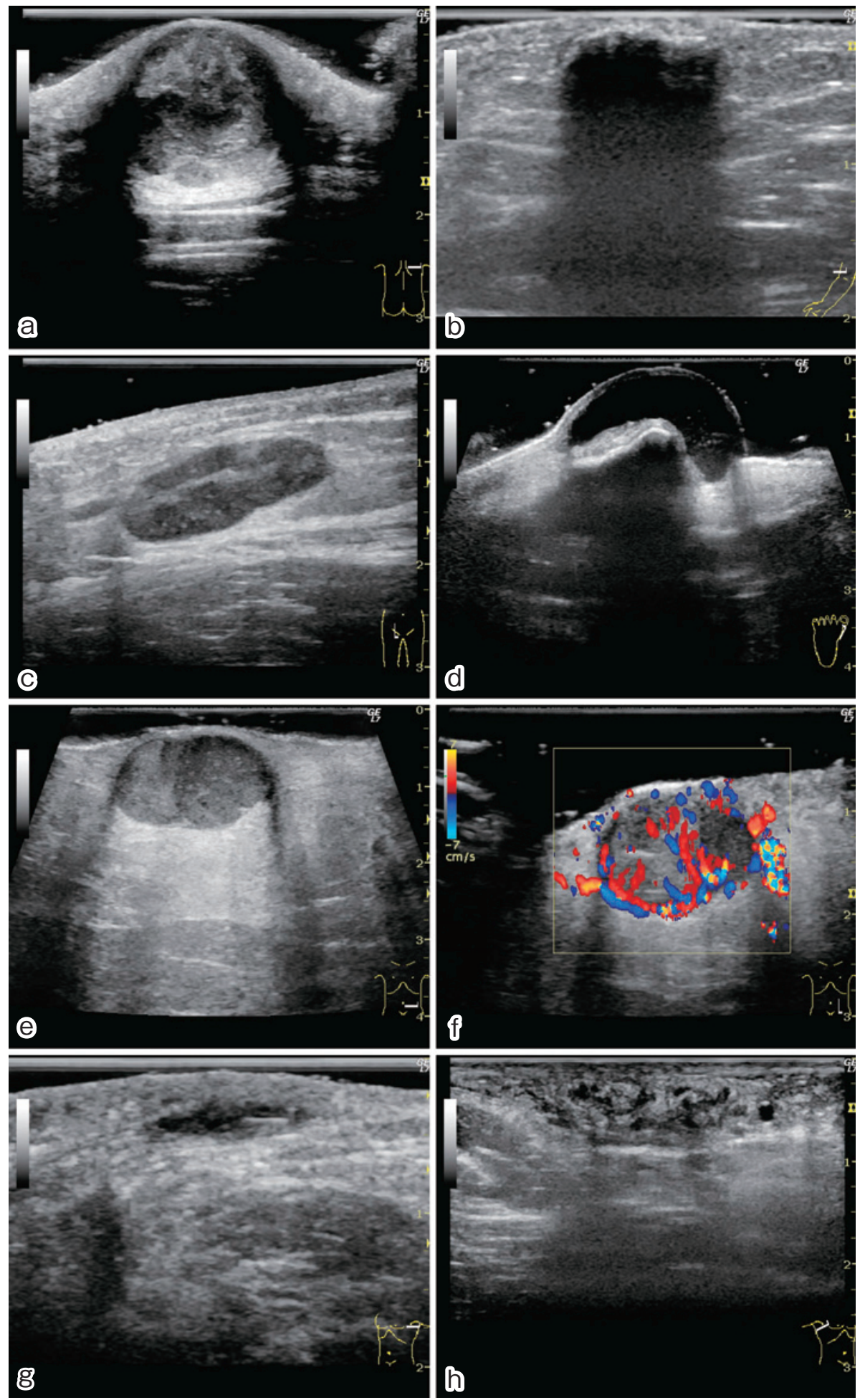

図 2

腫）：e では粉瘤のエコー所見に見えるが，f にて，内部の血流が豊富であり悪性が疑われ，生検により 診断された（粉瘤では内部は角化物のため血流はみられな
い). $\mathrm{g}$ : 毛巣洞：真皮内の低エコー領域内に線状の高エ コー (毛髪) が認められる. $\mathbf{h}$ ：副乳：真皮内に入り組ん だ低エコーの網状の領域 (乳腺組織) を認める. 